\title{
THE NEED TO PROVIDE ENGLISH COMMUNICATION SKILLS TO THE ENGINEERS AND THE QUANTITY SURVEYORS
}

\author{
Huma Adnan \\ Ms., MSB Dubai, The United Arab Emirates, humaadnan87@hotmail.com
}

\begin{abstract}
This study examined the need to provide English communication training to engineers and quantity surveyors (QS) in the United Arab Emirates. Engineers and quantity surveyors working in Dubai need communication skills training to use English effectively in their workplace. Moreover, to plan effective English as a Second Language (ESL) lessons for trainees, there is a need to conduct an Error Analysis from their written reports, which are submitted to UK based professional certification exam centre. Therefore, there is a global need for using English at engineering and quantity surveying workplace as English is a lingua franca. This research has identified the tasks that require English and common mistakes made by QS and engineers. The research has also discussed the existing curricula for engineers and their barriers. After collecting the results from survey and Error Analysis, a collaborative ESL program is developed. The findings indicate that there is a strong need to provide customized ESL training programs to the QS and engineers in UAE. It is also found that English is of great importance for the working professionals in listening, reading, writing and speaking skills. These findings are significant because they show that fluency in English is an essential requirement in today's world. The findings of the intervention also show that there is a need to provide ESL training integrated with Vygotsky's social constructivism theory. Moreover, the results also show that the Error Analysis can help in designing a useful course for corporate trainees. The paper recommends that such training programs should be provided to all types of profession for their career growth.
\end{abstract}

Keywords: Error Analysis, Engineers, ESL, Social Constructivism, etc.

\section{INTRODUCTION}

Globalization brings people from different nationalities in one workplace, and UAE is a country where people from all over the world work together. The need to speak and write English is essential for engineers and quantity surveyors. Although Arabic is a national language of UAE, it is English that is widely spoken by expats. Since the international market also requires communication in English, engineers who come from a different linguistic background, but live in Dubai need to communicate in global lingua franca which is English. However, most of the engineers, who are non-native speakers of English, are not well-prepared to talk or write in English, because Engineering colleges do not offer any long-term course on effective communication.

Firstly, engineering colleges already have many technical subjects because English is not taught as an 
extensive subject throughout their program. However, this does not mean that they do not require English in their workplace. Although we live in a world where software helps us to communicate in writing, one cannot ignore the need to have a deeper understanding of language to communicate without relying on the technology. Without the grammatical knowledge of any language, it is not appropriate to rely on autocorrections made by the software. Secondly, engineers need English for written and as well as oral communication.

The following research aims to focus to identify:

- English Needs analysis for engineers and quantity surveyors

- The common errors made by them in a classroom

\section{RESEARCH METHODOLOGY}

The survey questionnaire design is informed by Kassim and Ali (2010) which is divided into two sections and both the sections are close-ended. The questionnaires are distributed via print. The section one is designed to know the gaps existing in English communication skills of the participants. The second section focuses on the tasks that require English at their workplace. Out of the sample size of 20 participants, it is observed that 14 participants reveal that their listeners sometimes did not understand the conversation. Similarly, it is found that 14 participants sometimes avoid talking in groups and that number of participants who never avoid talking in a group and almost never avoid talking in the group is nil.

Eleven participants reveal that they often struggle with vocabulary and eight participants sometimes struggle with vocabulary, which gives enough reasons to understand the cause of why their listeners often struggle to understand. Nine participants often translate from native language to English and eight participants claimed that they sometimes translate from native language to English (fig 1.1).

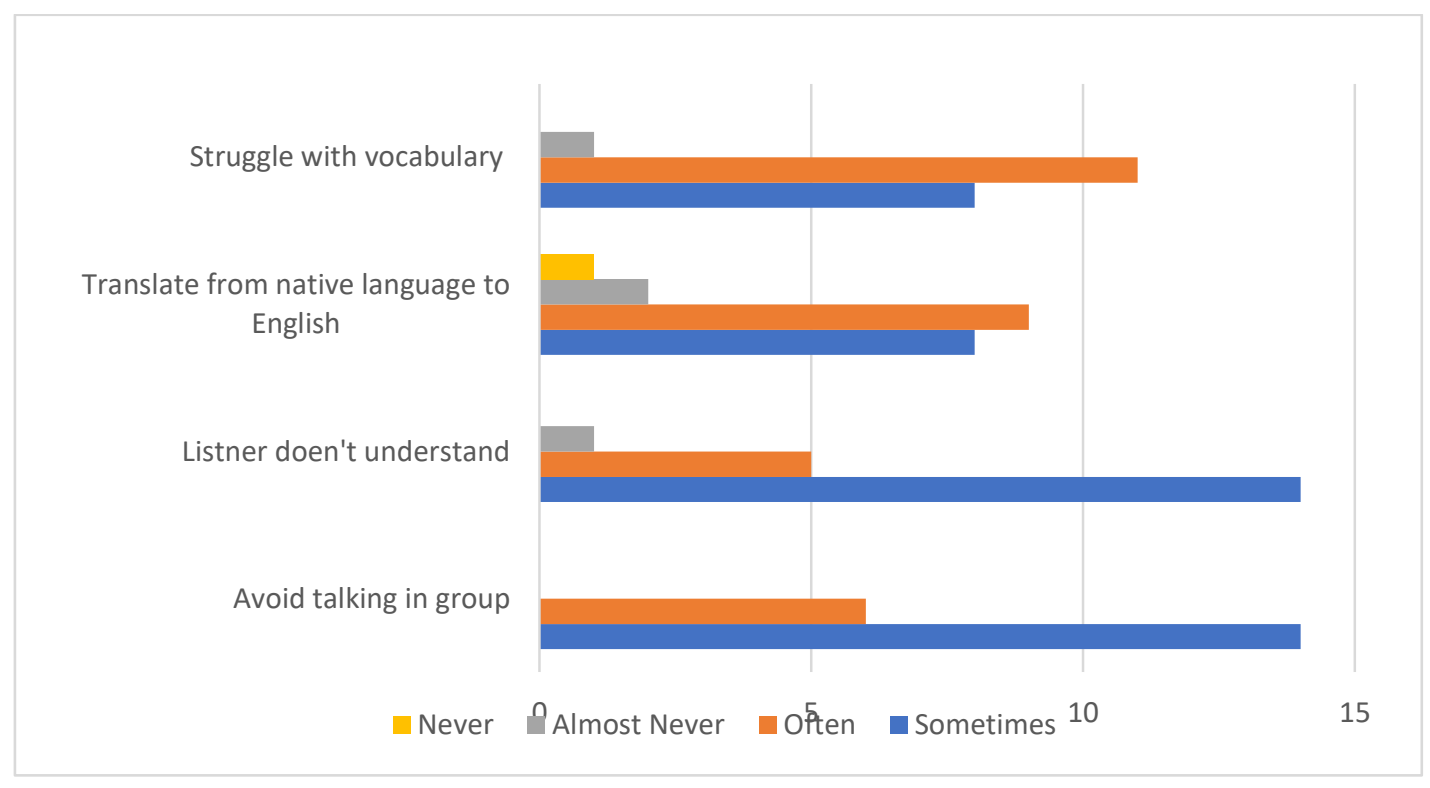

Figure: 1.1 Problems faced in communication by the participants

It gives an insight into why the participants often use fillers during their speech. The lack of vocabulary often leads to repeat the words. Moreover, it is observed in seminars that participants often used inappropriate or out of context words in their speech.

The results as shown in Fig 1.2 of the survey also shows, out of 20 participants, nine sometimes have difficulty in communicating ideas in writing, and four Often have difficulty in communicating ideas in writing. Moreover, it is found that 16 participants sometimes have difficulty in understanding the Non-Native speakers, which is more than the participants who sometimes have difficulty in understanding the native speakers. It shows that the participants do not have a massive issue in understanding native English speakers. However, the elements that drive one to speak language fluently such as vocabulary, grammar and tenses restrict them to convey what they wanted to say. 
Difficulty in communicating ideas in writing

Difficulty in writing emails

Difficulty in understanding non-native Speakers

Difficulty in understanding native speakers

Speak too slowly
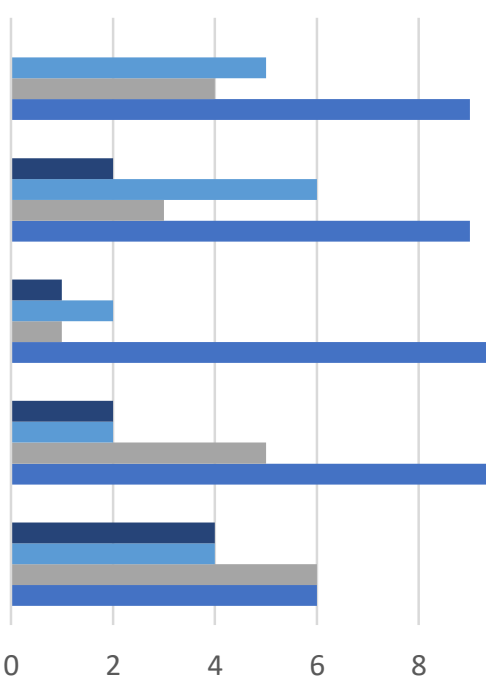

46

8

10

12

14

a Never Almost Never Often Sometimes

Figure: 1.2 Difficulty in written and spoken communication

Firstly, this observation is evidence that English usage is an essential element for the careers of the engineers. Furthermore, their level of competence on the language addresses the problems mentioned in Fig 1.2 where more than 18 participants (who responded with sometimes and often) have problems in communicating ideas in writing. The findings validate the issue for the participants, that results in a barrier in their way to achieving professional growth.

Through the second part of the survey as shown in figure 1.3, it is brought to the observation that these professionals heavily rely on English as a medium of conversation.

\begin{tabular}{|l|l|l|l|l|l|l|}
\hline \multicolumn{2}{|c|}{1} & 2 & 3 & 1 \\
\hline Reading business letters/business & 12 & 3 & 2 & 2 & 1 \\
\hline Reading memos/reports & 9 & 7 & 2 & 1 & 2 \\
\hline Listening to meetings & 13 & 5 & - & - & 1 \\
\hline Listening to group discussions & 13 & 4 & 2 & - & 2 \\
\hline $\begin{array}{l}\text { Speaking in English with native } \\
\text { speakers of English }\end{array}$ & 7 & 7 & 2 & 2 & 1 \\
\hline $\begin{array}{l}\text { Giving speeches/presentations in } \\
\text { English at work }\end{array}$ & 10 & 4 & 4 & 4 & 1 \\
\hline $\begin{array}{l}\text { Writing memos/reports } \\
\text { Writing presentation slides }\end{array}$ & 11 & 6 & 2 & - & 1 \\
\hline $\begin{array}{l}\text { Writing formal letters/emails } \\
\text { Discussing work related matters with } \\
\text { clients and colleagues }\end{array}$ & 10 & 7 & 1 & 1 & 3 \\
\hline Communicating via telephone & 11 & 4 & 2 & - & - & 1 \\
\hline Teleconferencing & 11 & 5 & 3 & 1 & 1 \\
\hline $\begin{array}{l}\text { Giving instructions to other people at } \\
\text { work }\end{array}$ & 8 & 8 & 3 & 1 & - \\
\hline Conversing informally & 9 & 5 & 5 & 1 & - \\
\hline
\end{tabular}

Figure: 1.3 Tasks that require English at the workplace 
The need of English plays an essential role in various critical communication elements in their everyday work tasks. For example, like reading business emails, listening to meetings, preparing and delivering a presentation, writing a formal email, communication via telephone, discussion of business with clients, delegating work or giving instructions to subordinates at work are the tasks that regularly require English (Fig: 1.3).

After thorough study, the researcher coordinated with Ms Rita of the organisation and built a course structure.

\section{CUSTOMISED COURSE}

The course is designed and informed by Vygotsky's theory of Social Constructivism. The course is for 24hours, and it is conducted in eight sessions. Different activities were included to avoid making the lessons monotonous. Every session would start with an activity and in between different videos would be played to make lessons more enjoyable. The grammar section was included on alternate days along with activities on pronunciation.

A course plan for the eight-day program was:

Day 1:

The importance of Communication skills

Good and Bad Communication

How to Improve Communication

Activity: Self-Introduction

Mind-mapping thoughts

Brainstorm ideas

Organize ideas

Activity: Group discussion

Day 2:

Grammar for effective spoken skills

Importance of Grammar

Essential elements of Grammar

Use of Tenses in various scenarios

The current scenario - Present Tense

Assessment and Activity

Importance of Prepositions

Assessment and Activity

Phonetics

/L/ and /R/ sounds

Activity: Listening and Practice

Vocabulary: Avoid Redundancies

Day 3:

Different styles of Communication

Body language

Voice projection: Stress, Intonation and Rhythm

Activity: Mini interview

Presentation skills with effective spoken skills 


\section{Structure Presentation}

Synthesize content

Activity

Key Expressions

Activity: Read, Synthesize, \& Speak

Day 4:

Grammar for effective spoken skills

Introduction to Past Tense

Assessment and Activity

Importance of Transitional Words

Assessment and Activity

Stress, Intonation and Rhythm

Vocabulary: Avoid Redundancies

Day 5:

How to persuade the audience

How to give an impromptu talk

How to control pace while speaking

Why is it important to control speed?

How to rehearse

Activity: Presentation

Day 6:

Grammar for effective spoken skills

Introduction to Future Tense

Assessment and Activity

Different types of sentences

How to improve sentences

Activity: Use the given words in sentences

How to improve vocabulary

\section{Verbose and erroneous expressions}

The results of the survey show that the engineers need to improve their grammar, pronunciation, speaking and vocabulary. The course is designed using various books (Appendix: $F$ ) after thoroughly assessing the need of the learners from Error Analysis and the survey. Each session is of four hours, so there is a need to keep the classroom interactive and energetic throughout the sessions. Thus, various group activities and presentations tasks are included. Moreover, to motivate them, it is announced that the after every session the best presenter will receive a prize and at the end of the course the certificate of performance will be given to all the participants.

The Managing Director, Ms Rita is willing to discuss the work critically. She keeps giving the feedback and advice to the researcher. There comes the point when the researcher needs to change the plan as per the knowledge of Ms Rita, who is consistently observing the sessions (McNiff, 2016).

Initially the simple examples are used to design the course; however, as per the recommendation of Ms Rita, the topics and examples are taken from the construction journals, alumni's written work. Similarly, the vocabulary is also used which is related to the construction field. The Director's guidance has helped the researcher in gaining the knowledge, and as suggested by McNiff (2016). this collaboration leads to organising the work. 
On day one, the participants are given an insight into the program. They are asked to introduce themselves. During a group discussion, it is observed by Ms Rita and researcher that most of the participants lack the confidence to speak in front of the audience. The researcher makes notes of the problems faced during the session, and these issues are improved in later sessions. For instance, on day one, most of the participants could not speak for more than one minute. Whereas, by the end of the sixth session, everyone participated in role play. The students in the classroom are divided into five groups, and each group is given a situation of the workplace to discuss. The students actively take part in the role play and show profound improvement.

During the rest of the sessions, each student will be asked to speak about the topic assigned to the previous class. It is observed that out of 22 only one has not shown much improvement, as the participant missed three sessions out of six due to travel. However, the rest of the learners show significant improvement. By the sixth session, the energy and confidence level is dramatically improved.

\section{FINDINGS}

Quantitative data analysis show that most of the participants, engineers and quantity surveyors feel the need to improve their English communication skills. The given pie chart shows that email writing and presentation skills are most performed tasks in QSs and engineers' work.

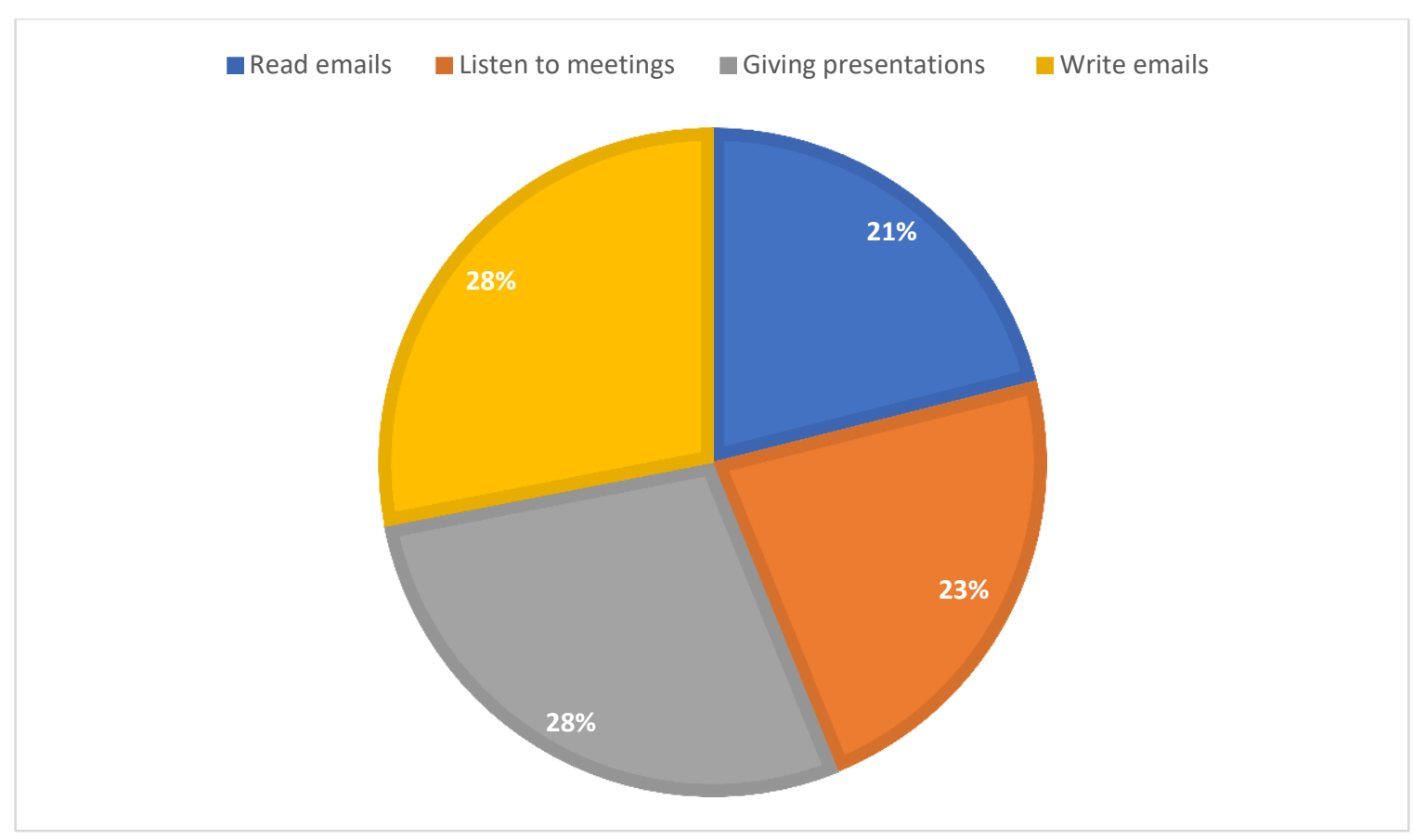

Figure: 1.4 Most performed tasks in QS's and Engineers' work

Overall, the data findings show that the use of English in all four skills, listening, reading, writing and speaking is equally of great importance. (Fig: 1.4)

For the qualitative data, the researcher conducts a pre-structured interview with the Managing Director by the end of the sixth session. In a question how vital was the program of effective communication for the participants, she answers that the alumni often faced the challenge in writing reports and received a referral in their Professional Competence interviews. Therefore, there was the need to introduce such course to them.

The second question was of what change did she observe in the learners' communication. She observes that participants were able to understand what were they lacking and what improvements they had to bring to overcome the barriers in their everyday communication. Moreover, the collaborative activities helped in making them confident and also increased the participation of the wary students.

The third question was how does she measure the success of the project. According to her, two elements are contributing to the success. Firstly, the ability of the participant to contribute to group discussions progressively increased. Secondly, the organisation has attained more recognition, and more people are interested in joining it.

The interview was conducted after taking consent from Ms Rita (Appendix E) 


\section{CONCLUSION}

The results of the research find that English is important for all skills at engineering workplace. It also shows that there is a need for English training programs for engineers and quantity surveyors.

Moreover, the error analysis helped this research in choosing the topics that were essential for the engineers and the quantity surveyors. It also validates Vygotsky's theory of social constructivism, which plays an essential role in ESL classroom (Oxford, 1997). The course proved to be highly useful for the professionals to become fluent in English.

By the end of the third session, Ms Rita decides to take feedback. The data shows that overall satisfaction of participants from the course was 4.5 out of 5 (Appendix D). The other element that contributes to the success of the intervention is the that participants have started to spread the word among their colleagues, and the organisation is receiving enquiries about the course. It is worth mentioning that for the first time this course is introduced in Dubai. Thus, the organisation has decided to expand this program further and has already announced the launch of the same program in Abu Dhabi, which commenced on $15^{\text {th }}$ March 2018.

Finally, the results of this program show that there is a constant need of addressing these programs to a broader audience of the same profession. The continuation of this program will enable them to convey their ideas and thoughts more efficiently. The improvement in communication can help them to meet the criteria of Chartered Surveyors assessments.

\section{REFERENCES AND BIBLIOGRAPHY}

Al-Khresheh, M.H. (2016) 'A review study of error analysis theory', International Journal of Humanities and Social Science Research, 2(1), pp. 49-59.

Berger, R.E. (2014) Writing for engineers and scientists. New Jersey: IEEE Press.

Bett, J. (2010) 'Error analysis: the ESL learners' dilemma', The International Journal of Learning,17 (1). pp. $525-535$

Barrett, N.E and Chen, L. (2011) 'English article errors in Taiwanese college students' EFL writing', Computational Linguistics and Chinese Language Processing, 16(3), pp. 1-120.

British Educational Research Association (BERA) (2011) Ethical guidelines for educational research. Available at: http://mdx.mrooms.net/pluginfile.php/1151664/mod_resource/content/1/BERA-Ethical Guidelines-2011.pdf (Accessed: 27 February 2018).

British Council (2013) Available at: https://www.britishcouncil.org/sites/default/files/english-effect-reportv2.pdf (Accessed: 10 May 2018).

Bolton, G (2010) Reflective Practice. SAGE: London

Brockbank, A and McGill, I (2007) Facilitating reflective learning in higher education. McGraw Hill: Backshire

Bush, T. (2012) 'Authenticity in research: reliability, validity and triangulation', in Briggs, A.R.J, Coleman, M and Morrison, M. (ed.) Research Methods in Educational Leadership and Management. London: SAGE, pp. 75-89

Clement, A and Murugavell, T. (2015) 'English for employability: a case study of the English language training need analysis for engineering students in India' English Language Teaching, 8(2), pp. 116125. doi: 10.5539/elt.v8n2p116.

Corder, S.P. (1981) Error analysis and interlangugae. Oxford: Oxford University Press.

Fox, D. (1983) 'Personal theories of teaching', Studies in Higher Education, 8, pp. 151-163. doi:10.1080/03075078312331379014

Draper, S. (2013) Social constructivism. Available at: http://www.psy.gla.ac.uk/ steve/courses/archive/CERE12-13-safari-archive/topic3/webarchiveindex.html (Accessed: 10 March 2018)

Dusen, E. V (2016) Mapping educational technology. Available at: https://erikvandusen.wordpress.com/2008/09/16/etec-511-assignment-1-mapping-educationaltechnology/ (Accessed: 27 March 2018) 
Dolasinski, M.J. (2004) Training the trainer. Prentice Hall: New Jersey

Evans, S. (2010) 'Business as usual: the use of English in the professional world in Hong Kong', Elsevier, 29(10), pp. 153-167.

Heydari, P and Bagheri, M.S. (2012) 'Error analysis: sources of L2 learners' errors', Theory and Practice in Language Studies, 2(8), pp. 1583-1589.

Hibberts, M.F and Johnson, R.B. (2012) 'Mixed methods research', in Briggs, A.R.J, Coleman, M and Morrison, M. (ed.) Research Methods in Educational Leadership and Management. London: SAGE, pp. $123-139$

Illeris, K. (2009) 'A comprehensive understanding of human learning', in Illeris, K. (ed.) Contemporary theories of learning. Oxon: Routledge, pp. 7-20.

Jarvis, P. (2009) 'Learning to be a person in a society: learning to be a me', in Illeris, K. (ed.) Contemporary theories of learning. Oxon: Routledge, pp. 21-34.

Johnson, K.E and Golombek, P.R (2011) 'The transformative power of narrative in second language teacher education', Tesol Quarterly, 45(3), 486-508.

Jung, N. (2013) 'Putting adult back into adult ESL education', International Journal of Arts and Sciences, 6(3), 557-579.

Kegan, R. (2009) 'What 'form' transforms? A constructive-developmental approach to transformative learning'. in Illeris, K. (ed.) Contemporary theories of learning. Oxon: Routledge, pp. 35-52.

Kassim, H. and Ali, F. (2010) 'English communicative events and skills needed at the workplace: Feedback from the industry', Elsevier, 29(10) pp. 168-182. Available at: http://www.sciencedirect.com/science/article/pii/S0889490609000635?via\%3Dihub (Accessed: 29 November 2017)

Kaewpet, C. (2009) 'Communication needs of Thai civil engineering students', Elsevier, 28(4), pp. 222-278

Kramberg-Walker, C. (1993) 'The need to provide writing support for academic engineers', IEEE Transactions of Professional Communication, 36(3), pp. 130-136

Kim, E.G and Shin, A (2014) 'Seeking an effective program to improve communication skills of Non-Englishspeaking graduate engineering students: The case of a Korean engineering college' IEEE Transactions of Professional Communication, 57(1), pp.41-54

Keane, A and Gibson, I.S (1999) 'Communication trends in engineering firms: Implications for undergraduate engineering courses', International Journal of Engineering Education,15(2), pp. 115-121. Available at: https://www.ijee.ie/articles/Vol15-2/ijee1067.pdf (Accessed: 28 November 2017)

Knievel, M, Heaney, A and Baalen-Wood, M.V. (2010) 'Breaking the rules: teaching grammar "wrong" for the right results in technical communication consulting for engineers', IEEE Transactions of Professional Communication, 53(1), pp. 58-68.

Moslehifara, M.A and Ibrahimb, N.A. (2012) 'English language oral communication needs at the workplace: feedback from human resource development trainees' Elsevier, , 66(12), pp. 529-536.

Norton, L.S. (2009) Action research in teaching and learning. Oxon: Routledge.

Orr, T. (2003) 'Introduction to the special issue', IEEE Transactions of Professional Communication, 46(3), pp. 153-156.

Oxford, R.L (1997) 'Cooperative learning, collaborative learning, and interaction: three communicative strands in the language classroom', Wiley, 81(4), 443-456.

Pritchard, A and Woollard. (2013) Psychology for the Classroom: Constructivism and Social Learning. Routledge.

Rider, M.L. (1954) 'Engineers are writers too', College English, 15(5), pp. 291-292. doi: 10.2307/372545.

Reinhardt, J. (2010) 'Directives in office hour consultations: a corpus-informed investigation of learner and expert usage', Elsevier, 29(1), 97-107.

Schwarzer, D. (2009) 'Best practices for teaching the "whole' adult ESL learner', Wiley Interscience, 121(9), pp. 25-33. doi: 10.1002/ace.322. 
Spence, P and Liu, G (2013) 'Engineering English and the high-tech industry: A case study

of an English needs analysis of process integration engineers at a semiconductor manufacturing company in Taiwan', English for Specific Purposes,32(2), pp. 97-109. Available at: http://www.sciencedirect.com/science/article/pii/S088949061200066X?via\%3Dihub (Accessed:28 November 2017)

Taylor, S. S. (2006) 'Assessment in client-based technical writing class: evolution of teacher and client standards', Technical Communication Quarterly, 12(2), pp. 111-139.

Tichy, H.J. (1988) Effective writing for engineers, managers, scientists. United States: Wiley-Blackwell

Veer, R.V.D. (2007) Lev Vygotsky. London: Bloomsbury.

Wallace, J. (1998) Action research for language teachers. Cambridge: Cambridge University Press.

Wardle, R.M. (1943) 'More English for engineers?', College English, 5(2), pp. 91-93. doi: 10.2307/370967.

Wheelan, L. (2010) Competency-based training, powerful knowledge and the working class', in Maton. K and Moore, R (ed.) Social realism, knowledge and the sociology of education. London: SAGE, pp. 93-111.

Whitcomb, C.A and Whitcomb, L.E (2013) Effective interpersonal and team communication skills for engineers. New Jersey: Willey.

Wilson, E. (2017) 'Carrying out and reporting on classroom-based research', in Wilson, E. (ed.) Schoolbased research. London: SAGE, pp. 77-102.

Young, M and Muller, J. (2010) 'Knowledge and truth in the sociology of education', in Maton. K and Moore, $\mathrm{R}$ (ed.) Social realism, knowledge and the sociology of education. London: SAGE, pp. 110-130 